\title{
Inscribing the Artifact and Inspiring Trust: The Changing Role of Markings in the Ming Era
}

\author{
Dagmar Schäfer
}

Received: 1 March 2010 / Accepted: 7 December 2010

(C) National Science Council, Taiwan 2011

\begin{abstract}
Inscriptions have mainly been discussed as an important source to aid the analysis of the nature and extent of state control over production and manufacture in Chinese history. This essay takes a different approach and discusses the conceptual development of inscriptions with a view toward their potential as an instrument to inspire trust. The aim is new insight into how Chinese culture historically implemented, expressed, and received rights within material production. This reveals some of the factors that affected practical knowledge transmission in Chinese culture. Starting with inscribed bricks, the article dissects textual sources and the complex world of inscribed artifacts and their purposes. The Ming state originally established the practice of inscribing names and dates to regulate responsibilities and rights within material production. Toward the end of the Ming period, the private sector increasingly focused on inscriptions as a means to propagate the origin and ownership of goods. Inscriptions thus were utilized to regulate both production and use. How did the Ming state conceptualize inscriptions? On which basis could the shift from production marker to ownership claim take place, and how was it received? The answers to these and similar questions are highly relevant, as methods of control and their implementation indicate actual practices of appropriation, in contrast to the ideals pursued in official or private documentation. Situating utilitarian usages within the larger landscape of inscription practices and regulatory mechanisms indicates the broader landscape within which technological development took place in Chinese culture.
\end{abstract}

Keywords Inscriptions · brand · markings · trust · state regulations · craft · Ming dynasty

In the year 1372 (Hongwu 5), about five years after assuming the throne, Zhu Yuanzhang 朱元璋 (1328-98, start of reign 1368) ordered his people to fortify his chosen capital, Yingtian fu (modern Nanjing) (Zhang Tingyu et al. 1991 [1736]: juan 74, Zhiguan 3, 1821). He decreed that the wall was to be built both up- and downhill 
expansively enough to facilitate the future growth of the city. Although this project was huge in scale, state historical accounts dedicate only a few sentences to it, focusing on basic accounting figures. Other literary reflections hail the wall as one of the many indications of the new dynasty's high morals and wise politics, conveying the impression that early Ming culture paid little attention to the details of the construction process. The material remnants, however, provide a different view of this era's perception of and dealings with craft know-how. Unlike the customary reinforced soil constructions, the wall was a massive brick structure, innovative in its technological approach. Rectangular in form, the bricks were almost all equal in size and weight, which implies that a standardization process was a part of the huge organizational and logistical efforts behind this achievement. In addition, elaborate inscriptions on the bricks expose the administrative and the operative hierarchy of people involved in production; they identify the officials and craftsmen by name, rank, position, or profession (Fig. 1). ${ }^{1}$ Managing the project, the Ming put their trust in inscriptions as a means of regulating material production. As it was stamped onto the long outer side of each brick, the inscription remained visible even after the wall was completed. This not only enabled a perpetuation of control; built into the city wall, the inscriptions were also a constant reminder of the state's sovereignty. The state put its faith in this form of public writing to advertise its seemingly ubiquitous power to the public.

In the modern world, the inscribed bricks of Nanjing have become in situ for tourists, and in topos for historians. Timothy Brook (1999: 19-24), Guo Jinhai (2001), and Fan Jinmin (1996) have already skillfully used them as a source for analyzing the organization of labor, socioeconomics, and technological development. Others, such as Zhou Yunzhong (2005), Sun Xun (2009), and Yang Guoqing (2002), have approached them within the context of political geography, labor organization, or calligraphy. This essay takes a different approach and uses the bricks like the end of a thread that, when pulled, will unravel the role of inscriptions within Chinese culture as a means to regulate the production and use of artifacts. As an everyday article, the brick represents the mundane use of inscriptions during the Ming dynasty, while the carefully arranged public display of the sheer mass of inscriptions on the wall (the inscriptions were mostly on the two lathy oblong sides, and thus at least one side of those used to make up the two external walls of the rampart around the city remained visible) draws attention to writing as an instrument for the advertisement, expression, and implementation of concerns and rights within material production beyond textual documentation. $^{2}$ The bricks of Nanjing are the material product (or evidence) of an institutionalized ideal at the inception of a new dynasty: inscribed with both administrative and labor-related information, each brick literally substantiates the implementation of a proposed order in which commoners and elite, rulers and ruled subjects jointly forged an empire and organized a state. Later, toward the end of the

\footnotetext{
${ }^{1}$ For a full description of the city wall construction see Yang Guoqing 楊國慶 and Wang Zhigao 王志高 2008. For an example of the brick inscriptions see the rubbings on pages $302-3$.

2 The Ming city wall had a diameter of ca. $14 \mathrm{~m}$ at the bottom and $4.9 \mathrm{~m}$ at the top. It was between 14 and $21 \mathrm{~m}$ high and was $33.6 \mathrm{~km}$ long. While the outside is enforced with larger stones up to a height of $5 \mathrm{~m}$, the bricks of the inside wall are easily accessible: assembling to a larger epigraphic image, the bricks of the Nanjing city wall constitute a public monument. Tackling the relation between forms of writing and power, this concern is part of a larger body of studies on the way in which Chinese elites, the public, and the state used writing within statecraft (Harris 1986; Kern 2001; Kraus 1991).
} 

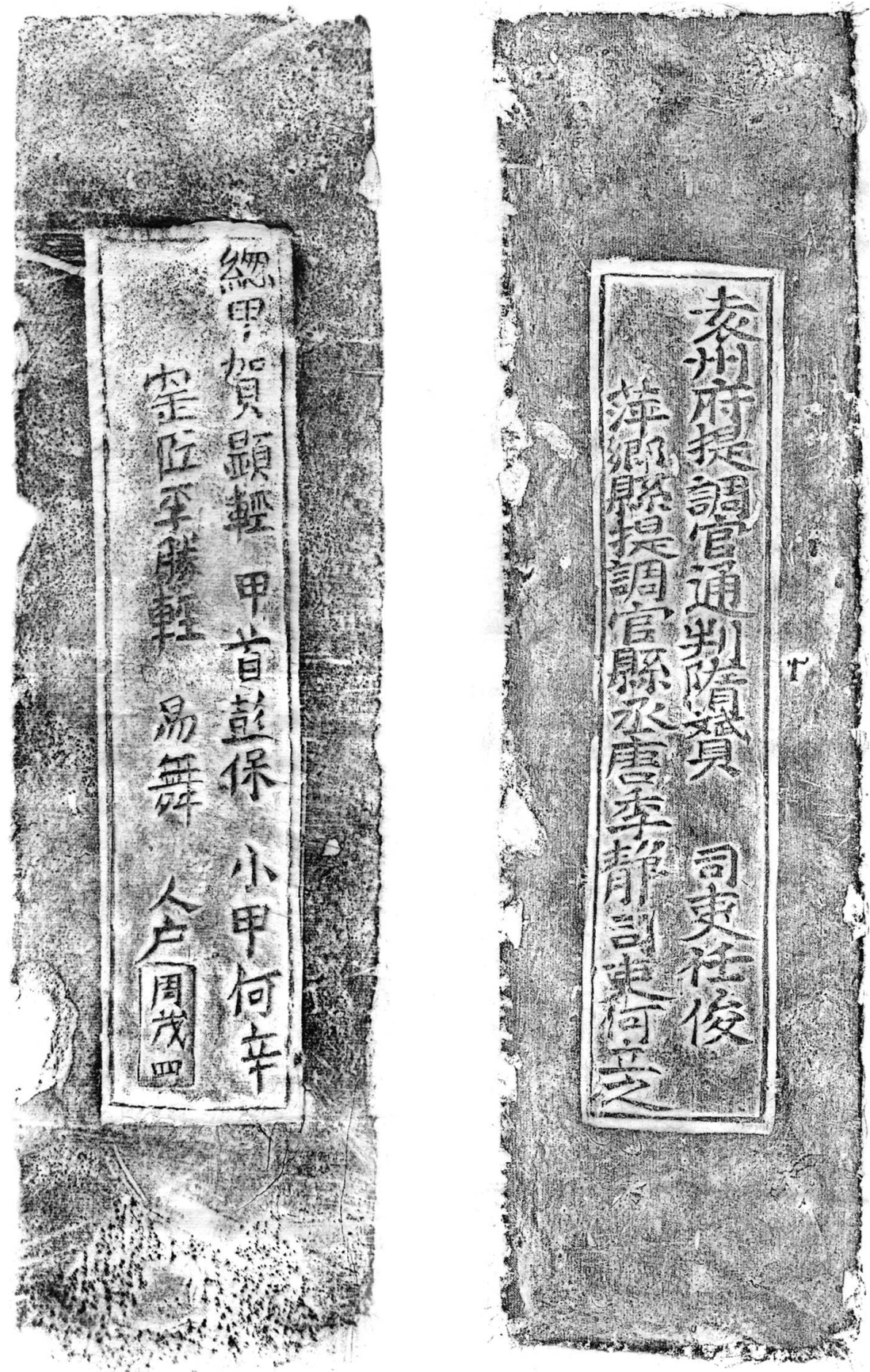

Fig. 1 Bricks of Nanjing city wall: $24.2 \mathrm{~cm} \times 10.2 \mathrm{~cm} \times 8.4 \mathrm{~cm}$. Inscriptions: (left) "Leadman He Xianqing, vice leadman Peng Bao, assistant He Xin, kiln master Li Shengqing, workers households of Zhou Maosi of Yiwu"; (right) "Sui Yun, assistant to the supervising official of Yuanzhou district Ren Jun, county assistant appointed by Pingxiang county supervising county assistant Tang Jijing, local official He Lizhi” (Yang Guoqing 2008: 187, ill. 0606). 
Ming dynasty, material culture suggests a growing discrepancy between ideal and reality. Through commercialization, inscriptions diversified in function and meaning. While these shifts have been recognized, little research has been done on their contemporary conceptual basis and reception in statecraft, private economy, and daily life. Did officials and scholars take note of them? Were laws and regulations adjusted? If not, how were these new functions introduced?

In Ming culture, inscriptions can convey information on the actual organization of production and the actual use of products. Name and date inscriptions regulated rights and responsibilities in the production process. Yet inscriptions also signified products' ownership and origin, and both of these traditions reformed and diversified by the end of the Ming. Inscriptions thus embody the consumption junction, as Ruth Schwartz Cowan (1987) has labeled the effect of use on technological development, on a quite instrumental level. Initially a regulatory instrument, inscriptions took over several functions at a time. Some of these functions have implications that can also be traced in the birth of branding, trademark, or patenting rights in early modern Europe. These implications rest, however, on concerns and traditions.

The key concept in the changing role of inscriptions is trust; in fact, we could argue that inscriptions during the Ming developed from an instrument meant to inspire trust (that is, a trust-invoking instrument) to a trusted symbol. The normative embedding of inscriptions plays a role in this development. Another significant feature is, more generally, their discussion in writing. Object traditions (that is, the continuity and presence of material culture) manifest the symbolism and offer another view of the conceptual, ritual, and social embedding within which inscriptions functioned. When texts and artifacts are juxtaposed, the ideals about inscriptive practices and its realities emerge, indicating the basis on which shifts in meaning and purpose could take place and revealing the significance of the broader culture within which inscriptions negotiated rights of production and use during Ming times.

Textual sources from the early or mid-Ming seldom reveal a concern with the trustworthiness of inscriptions. The technical specifics of the brick, however, reveal the contrary: the hierarchies of labor and administration are recounted on both sides of the brick, and the Ming took care that the inscription was carved deeply, inviolably tying the information to the object. The irrevocable connection of the inscription to the artifact was, as we will also see in other examples, one way the Ming inspired trust. The inscription had to be accomplished in such a way that removal of the inscription would damage the artifact, or at least the erasure would be visible. This includes the notion that a copy had to replicate not only the brick, but also the actual process of making the inscription. Some bricks even carry stamped inscriptions, which implies that a potential forger would have had to reproduce the object and the stamp. Within this context trust and reliability are a matter of playing out efficiency against desire. Desire is relevant, because it defines the actual (social, political, and/or monetary) value of the object. This value stands in relation to the investment for a reproduction: is copying the object worthwhile, and can a copy be efficiently achieved? The addition of an inscription complicates this process. The more complicated the technology or the greater the number of technologies combined, the higher the investment needed to produce a fake or reproduction and, consequently, the greater the trust in the validity of the inscription. Only by way of this extension of logic could inscriptions become more than just "written information," used to aid in the collection of taxes or to trace 
responsibilities. Inscriptions could change function and become in themselves an independent tool that enhanced the value of the product, or could carry completely different kinds of claims, such as the trust in the quality of the product, or its actual origin. Only then could inscriptions function as emblems of proprietary rights on the production and use of an artifact, as brands, or as advertisements of individual or workshop skills.

This article consists of three parts. The first introduces normative regulations concerning name and date inscriptions as a state instrument of control and discusses official Ming views of inspiring trust through technical specifications and administrative embedding. The regulations in the Ming official codex, Collected Statutes of the Great Ming (Da Ming huidian 大明會典) (Li Dongyang, Shen Shixing, et al. 2007 [1511; 1587]), attempted to ensure quality and secure tax payments by adding information about the production process to the product - specifically, in cases where that information was required by the state. I also trace the reception of these practices in texts and consider the problem of actual implementation. The second part discusses reign marks and the diversification of uses of inscriptions up until the early seventeenth century. In particular, the sixteenth-century object culture of the Ming reflects a complicated process of negotiation between institutionalized ideals of inscriptions and individualized and commercialized uses. The third part again takes up theoretical issues concerning the role and function of inscriptions. Throughout the essay, the juxtaposition of textual reflection with the actual practices of the period is employed to throw into relief the relationship between what actually happened and what got written about it; what was valid and how it was narrated and validated within the institutional setting or normative framework, and how this then reflected back on actual circumstances; and how the actual practice and the narrative confirmation thereof formed a self-reinforcing feedback loop. This draws attention to the tension between ideals and ideas of control over production technologies and reveals the dynamics between practices and textual manifestations in the constitution of new claims, subjects, and objects. Ideas about the causal relationship between practical application, textual reflection, and normative underpinning can be tested. Textual enforcement and material practice appear as equal instruments within a complex process meant to inspire trust, negotiate rights, and appropriate fields of expertise within material production.

\section{Guarantee on Display: Ming State Regulations on the Marking of Artifacts}

A rich corpus of historical studies emphasizes the diverse landscape of arts and crafts production in the Ming period. It was a period in which high officials organized and discussed lacquerwares, silk, and tea; emperors were concerned about arts and crafts in general and the production of porcelain wares, salt, and iron in particular; and an urbanized elite literati reflected on increased specialization and engendering of professions and the multifariousness of the thing world that colored their contemporary life (Bray 1997). An important incentive to these developments was the state's integration of manufacture into its governance system. Within this framework the Ming statutes promoted marking practices as a way to guarantee quality and regulate tax. 
Officials meticulously specified methods and contents with regard to materials and purpose to define responsibilities within material production. If the rules were implemented, the Ming world was systematically inscribed to display the control of production and advertise imperial power.

Ming official records attribute the inclusion of craft manufacture in state governance to their dynastic progenitor's interest in that field. Indeed, Zhu Yuanzhang had explicitly included craftsmen and artisans (bai gong jiyi 百工技藝) in his promise of righteous rule (Li Dongyang, Shen Shixing, et al. 2007 [1511; 1587]: juan 80 [Libu 38], 1a [1259]). Ming scholars also felt the need to weave in intellectual threads, arguing that the first emperor had been particularly enthusiastic about the Artificer's Record (Kaogong ji 考工記) and the classic Rites of Zhou (Zhou li 周禮), a text corpus that authorized the inscription of craftsmen's names for quality control within state ritual purposes. Considering Zhu Yuanzhang's humble background and a life dominated by military conflicts, this may have been only wishful thinking on the part of the literary-oriented elite (Farmer 1995: 6). Whatever the reason, Zhu Yuanzhang and his government established a complex, close-meshed monitoring system that helped to guarantee the quality of the material wares produced for the state. The Collected Statutes of the Great Ming unveils the wide field of products on which markings were commonly applied. A sensitive sector for quality control was the production of weapons of all kinds. In this sector official documentation is almost intact, and it indicates that markings never went completely out of usage. If they were temporarily suspended, officials complained loudly. A memorandum of the year 1628 (Chongzhen 1 , seventh month) shows that Ming officials also included new weaponry from the West in this system. Firearms and cannons made by the missionaries fell under the same rule as armor suits, bows and arrows, or knives. The names of the supervising officials and craftsmen had to be inscribed before they could be delivered to their final destination (Jin Risheng 2002 [1628-44]: juan 3, Zhaofeng 41). Artifactual evidence for this practice, however, is lacking. Instead cannons carry a reign mark.

According to the Collected Statutes of the Great Ming, markings were obligatory for the imperial commissions of furs, baskets, caskets, belt buckles, or silverwares and products such as oxen carriages. In the case of the oxen carriage, the quality issue was combined with an early version of the modern Ministry of Transport automobile safety report or compliance with safety standards. When commissioning carts, the officials had to ensure that “a list is compiled [bianhao 編號]. Brand the mark [yinlao 印烙] [to each carriage] and note this down in the registry so as to allow an investigation of the responsible officials and the responsible craftsmen workshops and its correction in case the carriage is not stable" (Li Dongyang, Shen Shixing, et al. 2007 [1511; 1587]: juan 200 [Gongbu 20], 39a-b [2702]). In all these cases the Collected Statutes of the Great Ming meticulously delineated the way in which products were to be marked. One sector in which inscriptions were verifiably employed and frequently consulted to keep tabs on materials and labor was that of shipbuilding. In the year 1484 (Chenghua 21), for example, officials had to control the brands to ensure that Huguang, Jingzhou, and Hangzhou of Zhejiang Province had delivered their share of wood. In this case materials were reused; thus the brand had to be changed (Li Dongyang, Shen Shixing, et al. 2007 [1511; 1587]: juan 200 [Gongbu 20], 6b [2685], 7a/b [2686], 10b [2687]). In the year 1546 (Jiajing 26) Zheyang district postponed its annual tax quota delivery to the year 1547. The Collected Statutes of the Great Ming notes that in this case the 
central government was permitted "to deliver the materials via the Supervisorate of the River Guard [wei he tiju si 衛河提舉司]. It is not necessary to replicate [chongfu 重複] [the mark] so as to avoid further delay" (Li Dongyang, Shen Shixing, et al. 2007 [1511; 1587]: juan 200 [Gongbu 20], 8a [2686]). If it is true that exceptions prove the rule, then we must assume that markings were generally applied on Ming dynastic ships and that officials thought them reliable markers for quality and tax payment.

The shipbuilding industry demonstrates vividly the comprehensiveness of marking practices. All incoming materials had to be inscribed. This information was then noted in the account books to substantiate the delivery of taxes. After completion, the responsible officials had to incise the names of all involved craftsmen and officials on the final boat or ship. Liang Menglong's 梁夢龍 (1527-1602) New Study on Sea Waterways (Haiyun xinkao 海運新考) in the section on “accounting” ( jikai 計開) suggests that this practice was continued throughout the Ming. "The carpenters and administrators constructing the body of grain tributary boats [cao chuan 漕船] have to use solid wood and set the nails closely together. Finally all department officials [jian guan 監管] and craftsmen [jiangzuo 近作] have to carve [ke 刻] their full names [xingming 姓名] on the stern [chuanwei 船尾]" (Li Dongyang, Shen Shixing, et al. 2007 [1511; 1587]: juan 200 [Gongbu 20], 25b-26a [2695]). ${ }^{3}$ The Collected Statutes of the Great Ming records a decree of 1471. Liang recounts a 1572 proposal of following this decree that had yet to be completely approved. Thus both sources note the idea, but they give no evidence as to the actual implementation of the practice. If the state workshops had carried out the decree to the letter for official ships, their sterns would have been covered from top to bottom with graffiti made up of names, ranks, and professions. What speaks against the possibility that this ruling was ever implemented is the fact that almost all excavation reports on Ming ships date their findings with reference to the cargo, not to inscriptions. In my revision of archaeological excavations, I did not find a single case of a grain or tax ship with such an inscription. ${ }^{4}$ This pattern can be discerned in almost all cases: texts describe a practice whose actual implementation is hard to corroborate.

According to Liu Sijie's 劉斯潔 (jinshi 1547) Investigations of the Imperial Granary (Tai cang kao 太倉考) (1999 [1580]), the regulation of marking responsibilities onto the final product also extended to large-scale buildings. Involved in the production of a new storage building in the year 1576 (Wanli 3), he mentioned that the officials and artisans had to carve their names on their work after completion: "The secretary of the office of scrutiny for Works [gongke jishi zhong 工科給事中, rank 5b] $\mathrm{Hu} \mathrm{Ru}$ 胡汝 has to supervise this process. If the building is deficient, [the craftsmen and officials] must repair the damage and pay a penalty" (Liu Sijie 1999 [1580]: juan $27,35 \mathrm{~b}$ ). The architectural remnants suggest that craftsmen inscribed marks on beams and planks for technical reasons, to indicate where they should be placed and posi-

\footnotetext{
3 See also Liang Menglong 梁夢龍 and Wu Zhong 吳仲 1981 (1578; 1940): juan xia, 52.

4 I found only one mention of an inscription on two river ships excavated in Liangshan. They were dated by their freight (He Guoweng and Tang Zhifa 1998). Furthermore, in the year 1975 a team of archaeologists excavated riverboats in Nankai, Cixian (modern Heibei Province), which had an inscription on their purpose and origin “Zhangdefen sheng liangchuan 彰德分省糧船 grain tribute ships of Zhengdefen” (Zhu Jingcheng 1978: 397). Thus far I have not found any evidence of an inscription of the kind proposed in the Ming Statutes.
} 
tioned. Only important showpieces were marked with personal names, if at all. Liu's remark, however, stipulated that the names of the responsible officials should be placed in a visible spot together with those of the involved craftsmen to facilitate quality control and serve as a guarantee. Again, there is no artifactual evidence of this ruling, which suggests that the text affirmed an ideal, not an actual practice.

In the case of ships, or the construction of granaries or storage houses, the state required individual names to be inscribed by hand. Probably an official took over this task, listing all the names rather than making each individual subscribe his name personally on the final object. If the markings could not be corrected after the completion of the object, the Collected Statutes of the Great Ming proclaimed that a nearby school had to be consulted to prepare and proofread the calligraphy. This was, according to the text, the case for all cast-metal objects. Interestingly, no further specification, such as to distinguish between ritual or utilitarian usage, is given, which supports the notion that regulations of the central state gave only a general framework and adoption happened locally. Officials had to ensure that "the names of the craftsman [and] workshops [jiangzuo xingming 近作姓名] and the production dates appeared on the finished product in the officially correct manner. Attending to their duty, the officials have to collate the brand [yinlao 印烙] before its actual execution is allowed" (Li Dongyang, Shen Shixing, et al. 2007 [1511; 1587]: juan 37 [Hubu 24], 29a-b [696]; see also Qiu Jun 1988 [1506]: juan 95, 6b). Specifying the calligraphy of the inscription, the state paid tribute to the high investment in the production of weaponry, iron, or steel implements. The functional inscription of a cast-bronze vessel also had to comply with aesthetic considerations. Erroneous or poorly executed characters could render the ritual purposes of the object null and void.

The case of cast objects is typical. It exemplifies that the Ming rules commonly favored marking practices that wedded information on the makers and those responsible for production (in the broadest sense, including the managers) inextricably to the product. This is not only the case for civilian production, where it may have been the most feasible method to secure retracing. In regard to ordering state wares, the state's official code also insisted on inscribing those responsible for the labor when the manufacture took place under full state surveillance, as in weapon, silk, or lacquer production. Within these sectors, production officially remained even after the "single whip reforms" (yi tiao bianfa 一條鞭法) under state survey. Organizing production in the state-owned workshops or regulating supply and demand by way of agencies, official documentation noted the employed and recruited craftsmen, on the local level from household registries and manufacturing sites and on the regional level during transport and on delivery. This documentation was more than sufficient to locate the maker. Still, the names of all responsible people had to be additionally “carved” (ke 刻) or "branded” (yinlao 印烙, huoyin 火印) and thus irreversibly attached to the artifacts.

Bricks are hence almost an exception in that they corroborate inscriptions as an implemented practice. Marked bricks can be found in more or less all city walls throughout the Ming empire. This proves either that the state and its regional representatives consistently enforced its policy or that Ming city officials shared a common culture and understanding of the purpose of inscriptions. However, only a few places, such as Xi' an and Jingzhou, can compete with Nanjing or Beijing in terms of the length of inscriptions and the quantity of inscribed bricks. Whether the inscriptions were ever 
actually consulted for quality reasons or used as an open archive for the recruitment or substantiation of workforce and materials is difficult to determine. The fact that names often concur could also be a sheer coincidence (Wang Kechang, Wei Liping, and Yang Xianwen 1999: 174; Guo Jinhai 2001; Xia Minghua 2003).

In the case of the Nanjing bricks, the Ming officials took the task of inscribing product information on the manufactured object seriously, with a propensity to exaggeration. They combined what the Song dynasty had distinguished as "the carving of craftsmen names" (wule gongming 物勒工名) and “the carving of officials' names" (wule guanming 物勒官名), and thus the long narrow sides of the oblong bricks, quite mundane articles, were often completely covered with characters (Li Tao 1986 [1881]: juan 196)..$^{5}$ This method of "double insurance" on mundane articles such as bricks suggests that the Ming officials were overly concerned with deficiencies in craft manufacture. But in my view it is even more likely that the aim was to display the effectiveness of imperial rulership, not the actual control of material production. After all, the inscribed city wall of Nanjing was living evidence that all regions had contributed their mite to the construction of the capital.

A similar argument can be made for the elaborate inscriptions found on the silk bolts excavated from the Ming imperial tombs. Here the term inscription does not really fit, although the Ming discussed silk along these lines in their official code. As the material was fragile, weaving offices (zhizao ju 織造局) had to "apply a sealed banderole [yaofeng 腰封] recording the number [hao 號] and the names of the supervising and managing officials and clerks as well as the craftsmen and workshops involved in the production. In case the product could not be used, prosecution proceeded according to these records" (Li Dongyang, Shen Shixing, et al. 2007 [1511; 1587]: juan 201 [Gongbu 21], 1b-2a [2703]). Strictly controlling silk, the Ming stood in line with the Song. ${ }^{6}$ Silk bolts from the Dingling tomb ${ }^{7}$ of the Wanli Emperor (born 1563, reign 1572-1620) show elaborate inscriptions of all kinds. Bolt number D65 of the Dingling tomb of the Wanli Emperor (Luchou silk in deep red and purple, da hong shan zhen zi xi hua Luchou 大红閃真紫细花潞绸) was signed at its selvage with an ink script naming the product and the entire line of officials and craftsmen involved in its production and delivery, from the ordering entity down to the actual weaving household. Other banderoles specify the product name, place and time of production, sizes, and weights, as well as the names and tasks of all participating artisans; exceptional cases (for example, banderole W121) also name the foremen and owners of the workshops (Wang Xiuling 2001: 86). Such expressions of control issues in the silk sector, like those in brick making, were reserved for special cases. They conveyed a symbolic message, namely, of accomplished imperial rulership. In addition, officials may have insisted on a complete record of their ranks and names for

\footnotetext{
5 See also Xu Song 徐松 (1781-1848) (1957 [1809]; 1936: juan Yunqi, 3570).

${ }^{6}$ Similar to the Song, the Ming thus admitted to the fact that silk was an important political means, trading in loyalty from its subjects and peace from the neighbors. The Song often discussed silk together with weapons and also prosecuted fraud and deficiencies along the same lines (Carré and Lamouroux 2010: 118-19).

${ }^{7}$ Buried here are three individuals: the Wanli Emperor (died 1620), Empress Wang (died 1620), and another Empress Wang (died 1611). It is the only tomb of the thirteen Ming emperors that has been excavated thus far. For the original excavation report see Changling fajue weiyuan hui gongzuo dui 長陵發掘委員會 工作隊 (1958 and 1959).
} 
representative reasons, or in the hope that their efforts would be rewarded. Regular silk bolts of the mid-Ming intended for imperial usages often show only an ink stamp, indicating that officials marked the material when it entered the storage rooms of the palace (Zhao Feng 2005: 22). The inscription is framed by a rectangle and stamped onto the selvage of the bolt. Similar bolts of the late Ming stored in the Nanjing Provincial Museum carry a much shorter inscription. Those of the early Qing name either the actual producing unit - whether an individual workshop or a state institution - or the office that financed the production and was responsible for quality control: the Liang Huai salt and transportation office and its supervisor (Liang Huai yanyun shi 兩淮鹽運使). ${ }^{8}$ Such inscriptions may have been more the rule than those found on burial wares.

In sum, the rulings suggest that the state was quite concerned about the trustworthiness of inscriptions and tried to find methods that linked the information reliably to the object. The juxtaposition of artifactual evidence also suggests, however, that rules were not systematically enforced in all sectors. In fact, it seems as if the state increasingly concentrated on representative functions and expanded the detail given in inscriptions for this purpose, thereby affirming an ideal. The bricks displayed imperial sovereignty. By contrast, the bolts found in the Dingling burial site were produced as grave furnishings and served a ritual function. Instead of inscriptions being written in ink on the cloth, early Qing silks weave the information about responsibilities and labor into the selvage. Most of them specify, as mentioned above, the responsible tax institution, such as the head of the Liang Huai salt distribution commission (Liang Huai yanyun si, yanyun shi 兩淮鹽運司, 鹽運使), not the producing unit. The actual configuration of the inscriptions hence suggests that the Qing rulers mainly aimed at emphasizing tax control and financing, whereas at least in principle, Ming selvage inscriptions enabled a retracing of the manufacturer. In either case we can see that by the late seventeenth century, even in silk manufacture, officials had found a feasible method for irreversibly attaching information about the production process and the individuals involved to the final product (Fig. 2). At the same time, however, if we look at the evidence for the actual implementation of the rules, the Ming never actually used inscriptions of names and dates to trace guarantee and tax payments. Instead the major function of inscriptions seems to have been to designate wares as being appropriated by and reserved for imperial or state-related usage.

According to the official regulations, porcelain, bronze, or lacquerwares were inscribed for the same reasons as silk, ships, or oxen carriages. The reign marks we find on these objects were a variation of the rubric of wule gongming. However, the actual form and content of the markings on these wares - that is, what we have come to call a reign mark - imply that the Ming state from the beginning conceptualized them along different lines, namely, as a signature of ownership of an innovative technology and rights in material production, and a symbol of imperial power and property. In diachronic comparison, reign marks are not a novelty as such. But in their systematic application they feature clearly as a novelty of the Ming, introduced silently without any additional normative validation. This abbreviated temporal identification of

\footnotetext{
${ }^{8}$ I was able to examine some examples during my visit at the Nanjing Provincial Museum in May 2009 with the help of Professor Jin Wen 金文.
} 


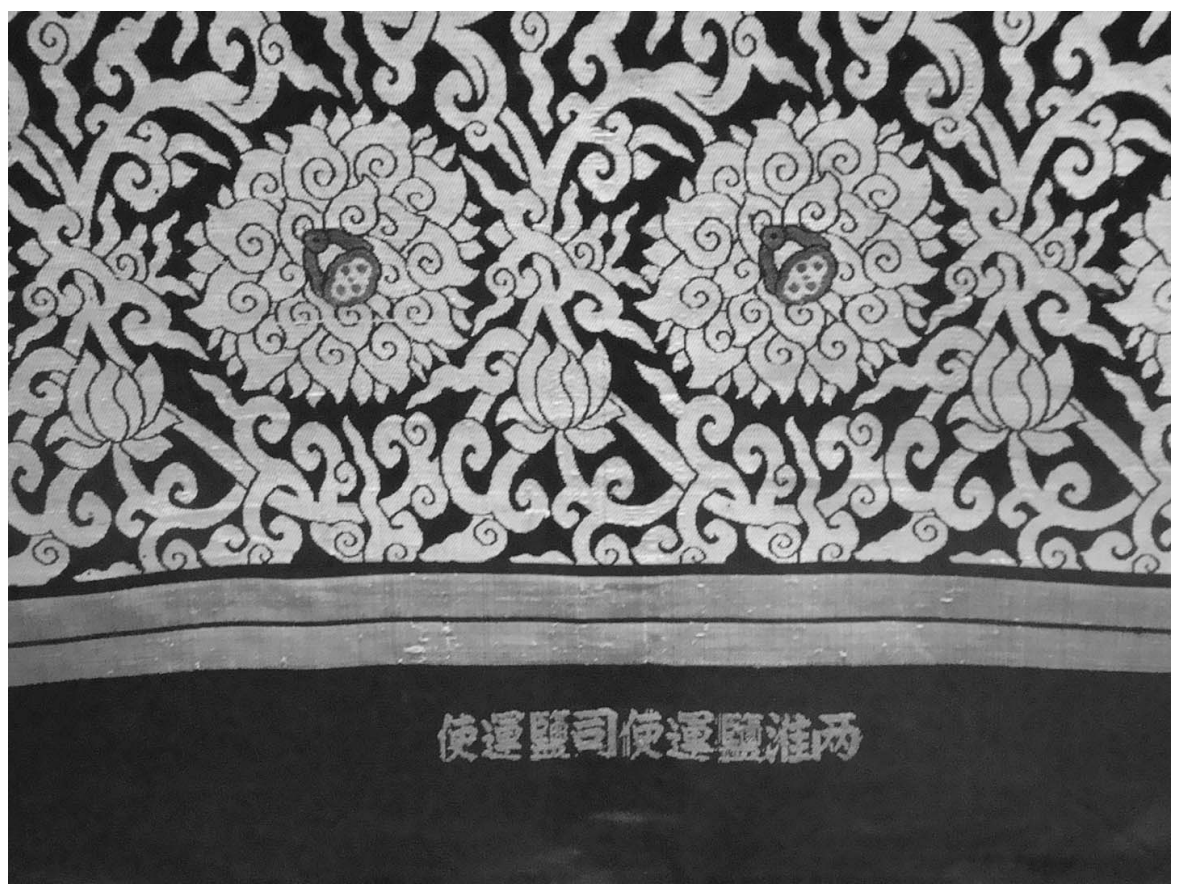

Fig. 2 Silk bolt with woven inscription, Qing dynasty: cloud brocade from Nanjing with inwoven gold and silver threads (jinzhi 金織). Inscription on the financing unit: "Lianghuai, whose transport supervisor ( yunshi) was also responsible for the transport of the bolts to the capital (兩淮鹽運使司鹽運使). Storage of the Nanjing bowu yuan 南京博物院” (private photo).

production no longer allowed origin to be effectively retraced, as the reign periods of Ming emperors could encompass several decades. Reign marks of the early Ming still varied in their purpose, depending on the object on which they were placed. The extended use of reign marks on material products with a function of status symbol and of ritual power affected the overall recognition of the purpose and implications of a reign mark on an object. It became a symbol of ownership and quality and a means of advertising the origin of wares. This rested on the state configuration of reign marks as part of a trajectory of marking functions within fields of state-owned silk and weaponry production or the acquisition of wares commissioned from the private sector. As political control loosened by the mid-Ming period, private industries found ways to build upon and extend state marking practices, particularly reign mark symbolism, into a varied landscape of marks that signified quality, individual creativity, and private ownership.

\section{Power on Display: Reign Marks in the Ming Dynasty}

Porcelain marks are a much-discussed issue in art history. Much of this research focuses on dating and ingenuity, and the mark as part of the design, or occasionally as a sign of technical change. Almost all research suggests that their major function 
within the state was the assignment of the production period (Sun Yan, Zhang Jian, and Wan Jinli 1999; Ma Xigui and Zhao Guanglin 2005; Feng Xianming 2007). Thus they are seen as in line with production inscriptions. If we believe the reports of collectors of the late Ming and throughout the Qing, inscriptions on porcelains were initially strictly controlled by the Ming state, and reign marks were allowed only on products produced for and used by the imperial court. If this specific rule on reign marks existed, it is not corroborated by administrative or normative frameworks. As mentioned earlier, existing documentation corroborates reign marks instead along the lines of wule gongming. Artifactual evidence suggests that reign marks superseded any other marking and that reign marks were initially restricted to particular material products: porcelain, bronzes, and lacquer. However, even in the early stages the state did not claim an exclusive right to the application of reign marks in its codex. All textual reflections on such restrictions come from the late Ming and early Qing period. Artifactual evidence, then, again suggests that the state actively monopolized the marking of these products to enhance the concept of defined imperial usage. In the early Ming few of the wares now at hand carry markings of private owners, users, commissioners, or producers. Clearly, preservation focuses on imperial and elite wares. With the later revival of these practices, the markings often imitated the state symbols in shape and content. In this way private marking practices undermined and at the same time supported the power inherent in the imperial marks.

Artifactual evidence also suggests that reign marks were an emerging concept, introduced and developed step by step. Interestingly, while other dynastic rulers had also used reign marks within their dates, the Ming seems to be the first dynasty to have systematically molded the use of reign marks, changing it from a dating practice or a practice of allocating usages into a method to brand goods, such as porcelain, as a matter of imperial concern. At the beginning a dragon, not a reign mark, signified imperial wares of the early Ming. Again the discrepancy between textual reflection and artifactual evidence is striking. Texts discuss only the necessity of designating “imperial objects for official use” (guanyong gongqi 官用供器) or allocating them for ritual purposes to the "altar" (tan 壇). The vast majority of inscriptions on porcelain and lacquerwares of this early date, however, advertise something completely different: “Produced in the time of the Great Ming” (Da Ming nian zao 大明年造) emphasizes the dynasty during which the product was made; this indicated that the Ming now had taken over from the Yuan. The third emperor, Yongle, then seems to have shifted to the reign period, unlike earlier periods that had specified the year of reign or even the day of production. The reductionist version of Ming made the retracing of responsibilities in fact impossible, even though officials in the state-owned manufactures carefully accounted even the slightest details. Indeed, the design and content of the reign marks suggest that this dynasty used reign marks to promulgate the exclusivity of its right to produce and use. The visual semiotics, which imitate the form of a seal or stamp, further support this claim. A stamp was a potent sign of individual authority in terms of origin and ownership, similar to a personal signature in the modern world.

For issues such as guaranteeing quality or ensuring liability, the reign mark was indeed useless. Only a fraction of the imperial wares were exclusively produced in the imperial kilns during the Ming. Some items were only "put together there, and then fired by civilians" (guanda minshao 官搭民燒) in privately owned kilns. Although the local officials had a great deal of control, the number of kilns was far too high and the 
wares too similar to retrace which craftsmen had actually made a specific object, particularly because most workshops worked with segmented modes of production. In fact, it may have been difficult to identify even the responsible official, especially when reign periods, extending over several years, covered various production campaigns. Yet the mark effectively displayed the dynasty's power and each ruler's proprietary right to porcelain. It is evident that this claim was not limited to the product, but extended to the technology and modes of production, when one takes into account that Ming period items that have reign marks are mostly porcelain, and very rarely ceramic wares.

A noticeable shift can be discerned by the Yongle reign of the third emperor, when wares increasingly specify the reign title. The practice of inscribing reign marks became fully fledged during the Xuande period, when a mass of utensils and objects spread the concept of imperially marked wares among the Ming populace and neighboring states. The late Ming scholar Xie Zhaozhe 謝肇淛 (1567-1624) remarks, “The system of the Xuande marks was most refined. Looking at the last 150 years, its value can only be compared to the Song wares. Then comes Jiajing, followed by Chenghua, and the golden altar wares of the final years of the Shizong come after that" (Xie Zhaozhe 1935 [1640]: juan 12, Wubu 4, 26). And in fact artifactual evidence supports Xie's remark. Wares with reign marks abound in the Xuande reign.

Xie also mentioned that the court produced a style sheet of the imperial mark with every order for the production of imperial wares: "The inner court [of my dynasty] promulgates a formal decree annually, handing out the styles [shi 式] for the reign titles [ji nianhao 紀年號]” (Xie Zhaozhe 1935 [1640]: juan 12,Wubu 4, 26). Archival documents of the Qing corroborate that this was a common practice within the sectors of porcelain, lacquer, and jade (Beijing tie yuan taoci yanjiuyuan 北京鐵源陶瓷研 究所, Zhongguo di yi lishi dang'an guan 中國第一歷史檔案館 2008: 34, 309). ${ }^{9}$ While marks of early Ming wares show a distinct set of character arrangement, style, and content, most of them are handwritten, implying that the painters at the kilns made freehand copies of the template on the wares. By the mid-Ming marks became more uniform. Michael Rowlands (1993: 144) suggests that "object traditions" serve as a crucial point of access to ongoing memory work. As culturally constructed entities, objects are used to connote and consolidate the possession of past events associated with their use of ownership. In this role the material culture itself, rather than textual confirmation, establishes the context and symbolism through which possession in the contemporary period takes place and is authorized. This is what seems to have happened with reign marks as a sign of imperial ownership by the 1580s.

Contemporaries of the early Ming rarely discussed reign marks or changes in their content, which suggests that audiences for wares with imperial marks were restricted. In fact, few scholars of the Ming had access to imperially produced wares. These wares remained at court or were bestowed to select honored subjects of the empire. Some were given to tributary states, such as Korea or Japan. Via these channels, imperially marked wares reached Arabian lands and eventually Europe (first also via Japan, particularly the Netherlands). ${ }^{10}$ As varying cultural ideas and concepts about practices

\footnotetext{
9 For an overview to the Qing see Wang Guangyao 王光堯 2010.

10 Dagh register 1602-82. De Hullu and the governor of Macao were discussing trade with China in 1673 (Hobson 1923: 168).
} 
such as inscribing wares merged, some issues were translated or transformed. This is particularly evident in the reproduction of Ming marks on Safavid porcelains (Golombek, Mason, and Proctor 2001). It was only by the end of the Ming, when the purely ritual and tributary function of porcelain production diversified and more and more wares were distributed within scholarly and elite households, that scholarly connoisseurs and collectors within Ming China started to notice reign marks and interpreted their visual and rhetoric symbolism to fit their collector's needs. In a sense this delayed public recognition of reign marks indicates that the courts' restrictions on the application of reign marks and the usage of such wares were quite effective even though the central state did not textually codify its application. It was only in the Wanli period that reign marks became pertinent issues within a larger context of ideas about copies, fakes, originality, and creativeness in material production. Here we have an exemplary case in which objects actually determine the paradigms for the collective memory of previous eras, and textual evidence takes a minor role. ${ }^{11}$ And it is from this point on that the literati discussed and distinguished the purpose of reign marks as signs of authenticity or its falsification. Addressing quality and forgery, they focused on the imperial production of the objects and ranked them accordingly.

Xie Zhaozhe employed reign marks as an identifier of eras, thus constructing a gauge for quality assignments. He did not, however, mention the issue of control or imperial power. Although few scholars recognized reign marks, many were concerned about the growing importance their era assigned to material culture and production. Gu Qiyuan 顧起元 (1565-1628) attributes this atmospheric change in his Idle Talk from the Guest's Seat (Kezuo zhuiyu 客座贅語) to the dominance of southern cultural and intellectual ideals within the state and society, an atmosphere he identifies as "most careful and honest" (Gu Qiyuan 2002 [1618]: juan 4, 4b). Other scholars of this period, however, did not share Gu Qiyuan's optimism; they depicted the diversified landscape of material wares as a dangerous development in which inscriptions provided no orientation. Wen Zhenheng 文震亨(1585-1645), for example, recognized the diversity of inscriptions and the difficulties this raises when using them to date or identify the origin of wares or their authenticity (Clunas 2004 [1991]: 79-80). But he was convinced this multiplicity was a sign of decay: as no higher order was regulating the application of reign marks, they had multiplied and diversified wildly. Inscriptions could no longer be trusted, and indeed Wen Zhenheng complained that in ancient times people "did not vainly add inscriptions, but valued only signatures. People nowadays investigate inscriptions only narrowly. Only long practice throughout generations brings esteem" (1984: juan 7, Qiju). Submitting to market forces, inscriptions had become an instrument of fraud, suggesting that the world was sliding into decadence and superficiality.

Only a generation later, scholars such as Gao Shiqi 高士奇 (1645-1704), in his Private Jottings of Gao Shiqi after Retirement (Jin'ao tuishi biji 金鳌退食筆記) (Gao Shiqi 1971 [1684]), explained the introduction of reign marks on lacquerwares by associating them with prominent Yuan lacquerwares, marked by individuals. Implications of this association are manifold on both the political and social level,

11 On objects and material culture in the creation of memory see Mills and Walker 2008. I use "collective memory" here in the sense of Thomas Abercrombie (1998: 15) as a historical dimension of culture. 
but particularly in the context of the Kangxi emperor's efforts to substantiate lacquerwares as a field under imperial scrutiny. By choosing the artist's practice as a point of reference, Gao equated the emperor with an artist and regarded a reign mark's proprietary claim as the equivalent of an individual producer mark. The Yongle emperor was for him the mighty proprietor of production, trade, and application. He was the source of making things, the creator: "The Yongle Emperor had a great interest in lacquerwares, and thus established a lacquer factory [Guoyuan chang 果園廠]. This factory produced red and black, engraved and inlaid lacquers. All of them were inscribed [with the mark] produced during the Yongle reign of the Great Ming [Da Ming Yongle zhizao 大明永樂製造] following the example of [the Yuan dynastic artists] Zhang Cheng 張成 and Yang Mao [Mou] 楊茂 who carved the lacquer in a facile style [literally: with a flying knife]. This was because the Yongle wares succeeded those of Zhang and Yang" (Gao Shiqi 1971 [1684]: juan xia, 20, 3b).

Gao advertised consistency as a major sign of imperial markings on lacquerwares. However, according to artifactual evidence only eight of the seventeen reign periods produced lacquers with reign marks. Quantitatively there was a huge increase in the Xuande and Hongzhi reigns and again during the Wanli period. Qualitatively the wares of the Jiajing, Longqing, Tianqi, and Chongzhen periods stand out. These periodic changes reflect the production cycles of the imperial lacquer bureau (Zhang Rong 1997). Qing writers ignore such shifts. Following Gao Shiqi's example, reports corroborated continuity in the practice and a consistency in imperial attitudes. Deeply concerned about the training of officials and literati culture, the assistant of the education department (xuezheng qianshi 學政僉事), Gu Yingtai 谷應泰 (1620-90), also emphasized this point. His appraisal of Shufu 樞府 wares in the Selected Readings on the Investigation of Things (Bowu yaolan 博物要覽) (1986 [ca. 1621-27]) promoted continuity as far back as Song times. Venerating a lost ideal, Gu identified the mark as an issue essentially contributing to the value of any piece of porcelain. As such the reign marks had become more than utilitarian: they themselves had become a meaningful instrument to advertise quality and origin.

\section{Inscriptions and Trust: The Negotiation of Interests}

The Ming was neither the only state nor the first actor to rely on inscriptions. And Ming officials used both material and textual sources to confirm the precedent and legitimize their use of this instrument. But if we take the bricks as an example, the Ming rulers were much more ambiguous than their predecessors in their use of inscriptions as a trust-invoking instrument: skeptical about the maintenance of technical standards, they had those responsible for labor and administration inscribed in great detail on the bricks; yet, confident in their imperial power, they entrusted the advertisement of their exclusive rights to the production and use of lacquer and porcelain to "reign marks" (nianhao 年號), diminishing the inscription of craftsmen's names to an almost symbolic act.

The Ming city bricks illustrate how Chinese states manipulated an array of instruments, appropriating use and production by the incorporation of manufacture in fields such as porcelain, salt, or silk into state governance. Inscriptions were one of many cogs in the huge and interventionist administrative apparatus of Ming culture. Within 
this context inscriptions proved to be a flexible instrument, useful in both private and state structures to extend the claim of ownership to the complex technological system, the concrete machinery and labor, the elusive knowledge and skills, and the volatile ideas that had made it. While the wall of bricks indeed reflects the hierarchy of labor and administration in great detail, the Ming took care that it was accompanied by other forms of documentation, such as the reports of officials and workers in local sources. One example of such local documentation is the 1553 report on the state-managed shipyard factory, Report on the Longjiang Shipyard Factory (Longjiang chuanchang $z h i$ 龍江船廠志), compiled by Li Zhaoxiang 李昭祥 (jinshi 1547). ${ }^{12}$ It details managerial tasks and lists working hours and materials. As a mechanism of control this textual information was quite effective, making each step of production the object of close scrutiny. Only as part of a complex set of documentation could the inscription serve to trace individual responsibility. And while Timothy Brook's analysis vividly illustrates this traceability in the case of the official, we can assume that the local artisan was traceable too, not only via the local official but also via the household registry system in which the local agencies had to record all men eligible to perform corvée labor for the state.

In the case of the bricks, the sheer mechanics of the inscriptions conveyed reliability when combined with other regulatory practices, such as defined standards. A traceless erasure of the inscription would affect the brick's size and weight and thus make it unfitting for state usage. One mechanism symbiotically confirmed the other: the erasure of the inscription implied that standards had not been met. The trustworthiness of the inscription was hence based on the identification of determined usages (as even with an erased inscription the brick could still fulfill its function). This recognition of defined usages is another factor that helped turn inscriptions into an effective instrument of trust.

Historiography often conveys the notion of continuities by sweeping over subtle shifts and regional diversity. Officials enforced mandatory usages to build trust and invoke reliability, especially if they felt their world was tottering. Scholars had recourse to the classics. There they found a precedent for the inscription of bricks as a means of controlling taxes and quality in material production: early works referred to the "inscription of craftsmen names" (wule gongming), situating the practice within a long tradition of dynastic governance. Material culture could serve the same purpose, corroborating the claim for continuity - at least as long as scholars agreed to group diversity under one common heading. Ming scholars and privateers, who after all enthusiastically followed the example of their Song colleagues and collected antiques from an idealized past, many of which featured inscriptions, thus felt no need to comment on variations in those inscriptions: perhaps during some periods they named individuals and during others they named institutions, but all were functional ways of tracing the maker.

Variations, however, occurred regularly on all levels: the range of inscribed artifacts changed, the notational form was adjusted, and the technology of inscription changed. Han lacquers or bronzes mention the year of production by number. Excavated Tang lacquerwares use the heavenly stems and earthly branches (utilitarian

$\overline{12}$ The date is of the first carving. It was reprinted by Jiangsu guji chubanshe in Nanjing in 1999. 
inscriptions hence verify the actual implementation of a shifting dating practice). On porcelain, the Southern Song shifted from incised marks to underglaze tax marks. Whether seen as cause or consequence, this change implies that the decision about the marking could be made at a different stage of production, namely, before the second firing, and not directly after the molding of the basic form. The surface continuity hides a pluralism of ideals and ideas, pointing to essential sociopolitical changes and shifts in each era's knowledge culture and its approach to technology: why, when, and how to appropriate and regulate it.

Another assumption is that each era has its distinctive characteristics. While at first sight this idea seemingly opposes the notion of continuity, we will see that it actually complies with it. In fact, Chinese intellectuals reinforced this view, to the point that forgers now and then rely on it. Thus oracle bones were by definition products of the earliest Chinese preimperial states. Inscribed bronze vessels for ritual purposes (which Song and Qing scholars venerated in particular) were identified with the Warring States period. Qin and Han scholars inscribed all kinds of tomb wares, life-size warriors, and fine lacquerwares to document production. Covering ceramics and lacquer with graffiti made up of lettering and painting is considered to be characteristic for the Tang. Minimalistic wares with single characters are representative of the Song. The Yuan exploited inscriptions as a method for the recruitment of labor and materials, a method that the Ming continued and that the Qing again faked and copied to "return to antiquity" ( $f u g u$ 復古) and lend credence to their rulership. This, of course, is an oversimplification, but it exemplifies the issues we consider relevant to each era. Conversely, artifactual evidence depicts, as Anthony Barbieri-Low (2007: 75-76, 138-52) among others has shown, a much more diverse landscape. By the end of the Han dynasty, for example, private entrepreneurs were already latching on inscriptions for advertisement and marketing purposes (Clunas 1997: 160; Wilson 1998). The subsequent loss of political control is shown in the resurfacing of a social struggle over the connotations and circulation of a practice or the management of material production. This struggle continued throughout the Tang dynasty, during which inscriptions became a major device of commercial culture. Yet in regard to inscription practice this dynasty is mainly recognized for the extensive usage of inscriptions on material objects as a way to commemorate major political events or rare private moments.

Whether or not these snapshots are now valid as such, they identify the issues that the Ming defined as tradition and that formed their legitimizing base. They refined the utilitarian usages of inscriptions employed by the Qin as well as the Yuan with two ends: on the one hand, they carefully regulated the usage of inscriptions as a method of quality control for the requisition of goods and materials for imperial purposes; on the other hand, they introduced reign marks as a sign of imperial property and power. Indeed, Barbieri-Low's research on pre-Han and Han dynastic culture shows that the Ming state was not original in making this claim, or in its methods; it was following a long tradition of state use of inscriptions for quality control and for stateorganizational purposes when it ordered the marking of bricks for the construction of the city walls of the two capitals, Nanjing and Beijing. Ming written culture also adhered to Han practice in another respect: in both periods, scholars lent authoritative power to the practice of imperial marks by referring to classical literature, the Yueling 
of the Book of Rites and a similar quotation in the Spring and Autumn Annals of Mr. Lü (Lüshi chunqiu 呂氏春秋). Both sources mentioned ritual objects. ${ }^{13}$ Ming scholars venerated the ideal of an unbroken tradition, in which Chinese states from the Han to the Ming (and indeed up to the late Qing) founded the normative authority of such measures of quality control and state authority on ritual codification, not on legal or worldly power. A good example is the early Ming minister of rites (libu shangshu 禮部尚書) Qiu Jun 丘濬 (1421-95), who warranted the regulation for the "carving of craftsmen's names" (wule gongming) on imperial wares (which served all kinds of everyday and sociopolitical needs) in his governmental handbook with a representative assembly of classic quotations on ritual wares, even though he was addressing wares of imperial production in general (Qiu Jun 1988 [1506]). At least for Qiu Jun, this issue of quality control lay at the heart of all functional inscriptions.

Their collections of antiques also forced scholars to define functional usages within a multitude of other inscription practices; for example, inscriptions could have ritual usages or decorative purposes, or could serve to convey classical texts or commemorate a social event. While Ming scholars writing on epigraphy and art eagerly identified separate usages, they placed the symbolism of inscriptions within a defined conceptual framework that was actually established by Song dynastic scholars. Systematizing the antiquarian study of inscriptions, Lü Dalin 呂大臨 (1046-92) or Wang Fu 王䊇 (1079-1126), referring to the ancient predecessors of the Nanjing city walls, grouped inscribed bricks along with stele epitaphs, bone inscriptions, carved seals, engraved coins, incised lacquer, and lettered pottery as a source for philological or historical analysis. Thus while a Ming connoisseur may have clearly distinguished a “postscript" (tiba 題咙) from the guaranteeing mark on a brick, he trusted the familiarity of the functional inscription. The authority of the inscription was confirmed by the framed square around the writing, reminiscent of an official seal. ${ }^{14}$

The term inscriptions hence embraces a variety of methods for attaching textual information to an object within Chinese culture. Whether written in the form of a narrative, documentation, or poem, inscriptions had ritual, utilitarian, social, and political functions. They identified people as owners of perfumes, soaps, or sideboards, or they specified the value or original materials of the object. Others located an object in space and/or time, signifying where it was made or stored. While some people elaborately asserted their relation to an artifact and disclosed its usage or origin, others simply noted the place or date of production. Art history traditionally distinguishes two conceptual traditions that fed into the Chinese epigraphic habit: "patterned seals” (feng 封, huajia kuan 花甲款) and “epigraphs” (kuanzhi 款識). While inscriptions specified events, people, or institutions, ranging from poetry to namedropping, seals authorized individual claims. Similar to the way a signature is used in modern times, a seal personalized things. The best-known examples are the collectors' marks on paintings or artworks of the late seventeenth and eighteenth centuries (Clunas 2004 [1991]: 124). In books and paintings it was a sign of ownership, that is, ex libris. The length is not always a guide to distinguishing between inscriptions and owners' marks. An inscription could be an epitaph, a single grapheme - that is,

\footnotetext{
13 For the original quotation see Cui Shi 崔定 1976?: Quan Shanggu 1: 725, Yan Kejun, Quan Hou Han wen jun 46: 7a. For an English translation see Barbieri-Low 2007: 76.

14 Handwriting or the uniqueness of the seal's characters played no significant role.
} 
a character as a pure decorative element or auspicious symbolism ("blessings" [ jiyan kuan 吉言款], “eulogizing sayings” [zansong kuan 讚頌款]). A mark of individual ownership was not necessarily short. Some examples on porcelain and bronzes feature elaborate lists of social and institutional affiliations.

Intellectuals reflected comprehensively on inscriptions on objects in the context of arts and crafts, and as a source for historical, linguistic, and philological studies. Different types of inscriptions may carry different meanings, and the same type of inscription may have different significance when applied on different types of objects. For instance, a name mark placed on a porcelain vase did not have the same function when applied to a painting. The first was defined as a "name mark" (kuanzhi); the second, as a "postscript" (tiba). The object hence determined the function. Still, their implications borrowed from one another: they both linked to an individual.

This may be a superficial indication of a common cultural context, but it was crucial to inspiring trust: the functional inscription worked only within this framework. The Qing was particularly enthusiastic about emphasizing such linkages to authorize their practice. It is the Qing lens that essentially directs our view to traditions and the continuities and ruptures within it. The Qing dynastic compilers of the Complete Library of the Four Treasuries (Siku quanshu 四庫全書) did not tackle inscriptions directly, yet they carefully classified texts dealing with such topics. Thus they decided that writings on paper (printed or as manuscript) had to be carefully distinguished from texts inscribed on stone or bronzes. Furthermore, the Siku compilers contended that the group of jinshi 金石 did not belong in the "specialized treatises" ( $p u l u$ 譜錄) section on historical objects. Instead, those texts that mainly dealt with "memorizing the inscribed text" (jilu guke tiao 記錄古刻條) should be classified as lists, whereas texts that noted inscription because of initial concern about the object should be classified under the category "specialized treatises" ( pulu) (Siku quanshu zongmu, juan 85, shibu, mulu lei yi, jingji, 733). ${ }^{15}$ Confronted with a broad heritage of varied inscriptions (extensive tracts, poetry, symbolic marks, and signatures) on a multitude of material objects (manuscripts, bamboo rods and books, bronze vessels, and powder tins), the compilers of the Siku quanshu then decided that certain functional inscriptions, name and institutional notifications and seals, and writings dealing with them comprised a group of their own (Siku quanshu zongmu: juan 86, shibu, mulu lei er, jinshi, 743).

My explanation of the Qing scholars' assessment is meant as more than a reminder of how this dynasty's historiographic and classificatory efforts still resonate. The Siku compilers suggested that each period also differed essentially in its focus and scope of reflection on the epigraphic habits of earlier times. They claimed that, for Song literati, epigraphy in its full scope-whether ritual or utilitarian, lengthy stele texts, tomb inscriptions, or singular characters inscribed on earthenware or bones - was an important topic and field of interest. It was during this era that scholars such as Shen Gua 沈括 (1031-95) invented the discipline of Chinese "epigraphy" (jinshi xue 金石學) (Wang Guowei 1927). The Yuan period was, according to them, much less vibrant.

\footnotetext{
15 See also Siebert 2006: 112-13. Siebert also notes (p. 123) that the bibliographical classification of “works on bricks" (wadang 瓦當, zhuan 磚) changed. Zhang Zhidong 張之洞 (1837-1909) incorporated writings dealing with the inscriptions on bricks into the category of "epigraphy" (jinshi xue), whereas the Baqianjuan lou 八千卷樓 arranges such works under the rubric of antiques.
} 
In actual fact, the major epigraphic dictionaries were compiled during the Yuan. The Qing Siku compilers assume that although the Song served Ming literati as their model, the Ming never achieved their range in the study of inscriptions. Indeed, both the Ming and the Qing scholars were not only avid producers of inscriptions (Lu Hejiu 1981) on stelae as well as on artifacts; they also produced remarkable studies in this field, discussing calligraphy, content, and philological issues. ${ }^{16}$ In the Ming state, inscriptions were systematically employed to advertise public buildings, commemorate state events, and venerate classic literature in so-called stele forests (beilin 碑林), and the Ming systematically employed and regulated their usage as a quality control (which the Qing noted and then claimed to have continued, albeit in an improved form). Extensive state use might have curbed intellectual engagement with epigraphy, particularly this era's interest in earlier utilitarian usages.

Historical research is naturally biased by the epigraphic customs of previous eras, that is, the general availability of materials. But it also tends to collect and analyze materials that corroborate preconceived notions and thus reconfirms itself. Venerating the past, Song and Qing scholars focused on early periods and ritual as well as social contents, a trend that is continued in archeological research in the modern People's Republic of China. Due to preservation practices, objects for elite or imperial usage make up most of our reference points. On the conceptual level, research generally favors bookish descriptions or administrative documentation, by pointing to, on the one hand, the high diversity of objects and their singularity and, on the other, the reflexivity of texts - that is, their generic quality. How regulations were actually implemented is seen as a minor issue. However, we have to concede that the textual manifestation of property regimes, judicative and normative underpinnings, were often symbolic. Patent assignments in sixteenth-century Venice, for example, conveyed exclusive rights to the owner for areas and regions well beyond the influence of the patentor, the Venetian state or the doge. At stake was not the enforcement of the patent, but the reputation of the owner and patentor (Patent Office Society 1936).

When considering inscriptions as an emblem for rights, one paradigm gradually losing ground within this context in Chinese history is the idea that the central state and its codex were a major regulative force. During the Qing, the central state only set the general framework in its codices, which were actually built on Ming precedents. ${ }^{17}$ Similarly, in the Ming the localities primarily elaborated the normative underpinnings concerning property rights and social interaction, although this may have happened in a more restricted way than was later the case in the Qing. All in all, we can assume that when the Ming government introduced and maintained state manufacture, it was within a prosperous and intellectually self-confident region with long craft traditions. The state had to enforce its general ideals and notions of all that belongs to the emperor, within a varied landscape of ideas on how to organize technology and thus also how to convey responsibilities and rights within production.

\footnotetext{
16 The Xi Qing gujian 西清古鑑 (40juan) aggregated between 1749 and 1755, the Xi Qing xujian jiabian 西 清續鑑甲編 (20 juan), and the Ningshou jiangu 寧壽鑑古 were compilations of ancient bronze vessels. Ink slabs were compiled in the Xi Qing yanpu 西清硯譜 (25 juan), and painting and calligraphy in the Midian zhulin 秘殿珠林 (24 juan), Shiqu baoji chubian 石渠寶笈初編, and Shiqu baoji xubian 石渠寶笈續編 catalogs. More than simple inventories of palace holdings, these catalogs outlined rudimentary taxonomies. 17 For the Qing dynasty, I refer to Reed 2000. See also Bernhardt 1999.
} 
The final topic covers clarifications on translations and terminology. Chinese literature addresses seals on artifacts generally as “studio marks” (tang ming 堂名). These studio marks designate the workplace or the location where the object was stored (others are zhai 齋 [studio], shuwu 書屋 [library], or xuan 軒 [pavilion]). An individual is identifiable behind this place-name. Curiously, from the tenth to twelfth century and then again after the fifteenth, marks mentioning only a name are quite rare. This indicates essential shifts in the way in which Chinese culture defined the relation between individual and object. Chinese scholars and historians of the early twentieth century, however, such as Xu Zhiheng 許之衡, lumped together individual names and assignments referring to a locality as one and the same. In the Discourse on Porcelain from the Yinliu Studio (Yinliu zhai shuci 飲流齋說瓷), Xu (1992: chap. 6, 77-81) distinguishes on this basis four social groups as originators of studio marks: "emperors and princes" (di wang 帝王); the “nobility” (qin gui 親貴), that is, the imperial family; high-ranked officials and "scholars" (ming shi 名士); and "refined artisans" ( ya jiang 雅匠) or “skilled workers" (liang gong 良工). For Xu the latter two terms identified artists and master craftsmen rather than ordinary artisans or laborers. In actual practice, inscriptions vary in form, content, and placement depending on social and functional aspects, yet such variations are far from consistent. It can be said that, by the Ming, scholars and nobles preferred the designation of their studio, whereas artists or artisans often applied their given name.

$\mathrm{Xu}$ 's social distinction implies an a priori assumption about the functionality of marks that research generally reproduces, namely, that emperors, nobility, and scholars, as well as traders, usually marked wares as owners, commissioners, or clients of wares, whereas artisans signed them as producers. A discussion of Yixing wares might complicate this distinction, however, as would an inquiry into late Ming seal carving. While researchers admit that assignment of ownership by an emperor or elite member can imply his creative participation in production, it seems to go without saying that an emperor would never have produced the object with his own hands. Yet while social norms may have made the recording of such activities inconceivable, the occurrence itself is not impossible. Another idea is that historically opaque persons can only be the artisans of the piece. In fact, however, inscriptions are quite indistinct: the textual information “Wang Yi produced" (zhi 製, zao 造, zuo 作) does not specify whether something was made for or by Wang Yi. This can only be interpreted by assessing all the information given by the inscription, including its actual placement. Research suggests prominent placement indicates an owner's mark. Conversely, an obscure placement suggests artisanal origin. In general, the sum of all kinds of informationwhether the inscription was stamped, written, painted, scratched, or engraved on the object; whether it was added before, during, or after the actual process of production; and whether it was placed at a prominent spot or hidden at the bottom, in small or big letters - provides the grounds for speculating about how much influence a client, emperor, scholar, or prince had on the production or the possibility that he only bought the product and signed it as an owner. Personal and studio names are often unique, and additional sources have to be consulted to reveal who actually stands behind these marks: whole clans or associative groupings, trade guilds, or commercial traders, institutions, or individual women or men (Pierson 1998).

From a more global perspective, it must be noted that the Chinese culture of inscription seems to have had no tradition of "marking" craftwork for technical 
reasons, as was done by English or German craftsmen or Japanese and Korean potters marking wares for use in shared kilns (Blair and Ramsay 1991). Most Chinese marks are also actually "writing": names are spelled out and information is textual. Symbols or graphic elements are rare. However, it cannot be ruled out that the written word was at the time (and in retrospect) also recognized as patterned meaning rather than textual information, especially when it came in the form of a seal. ${ }^{18}$

\section{Conclusion: Reign Marks as Signifiers of Quality and Ownership}

The wares preserved in museums and exhibited in collections suggest that reign marks dominated the practice of marking porcelain objects and that the number of wares increased continuously throughout the Ming. However, this is also due to selective preservation, which focuses on imperial and elite wares. As imperial kilns increased production, private industries grew too, producing an increasing number and variety of individual inscriptions. Private potters or entrepreneurs associated themselves with imperial markings to enhance the economic value of their wares. Private inscriptions of the Chenghua period almost all copy the reign marks in style: four characters surrounded by doubled square or circular frames (Fig. 3). Furthermore, the Ming rulers seem to have been eager to construct traditions and continuity within material culture. One indication for this is the marked similarity of porcelain marks from the Tianshun up until the Chenghua period. Imperial marks were all arranged in pairs of four or six characters in regular style. The reign title was followed by "produced in the year” (nian zao 年造) or “produced by/for” (zhizao 製造) to achieve this goal. The harmonized markings represented a harmonized rulership and a unified empire.

According to the codex of the early Ming state as reported from the Qing, inscriptions were employed to control quality and regulate taxes. But it looks as if this remained an ideal, enforced only in rare cases to invoke trust in imperial sovereignty. By the early fifteenth century, reign marks in the fields of porcelain, lacquerware, and bronze wares were a sign of imperial power in material production and use. On this basis the marks seem to have been recognized as features that enhanced wares' value. The diversification of markets and massive expansion in commodities that started in the mid-Ming was partly caused by the state's official withdrawal from many fields of production as it started to work openly with civilian producers to fulfill imperial demand. During this period imperial wares entered the market, dictating the standards and shaping the likings of the newly rising scholarly and rich merchant elite. In this first phase, the state and private craftsmen attached marks to bowls and cups rather than chairs, mirrors, or brushes. Faked or original, imperial or individualized, inscriptions of this era promoted a quality ideal: produced for imperial usage and thus of the best standard. ${ }^{19}$ While imperial marks had been copied and imitated before, private entrepreneurs now started to experiment with form and content on a much larger scale.

\footnotetext{
18 This surely happened with the transmission of objects to spheres in which writing was not used, or Chinese characters were not known. Irene A. Biermann (1998: xiii, 36-43) points to the changing role of written information in different alphabets, i.e., the communities for which they are not relevant.

19 On the shifts of Ming politics on crafts see Schäfer 1998.
} 

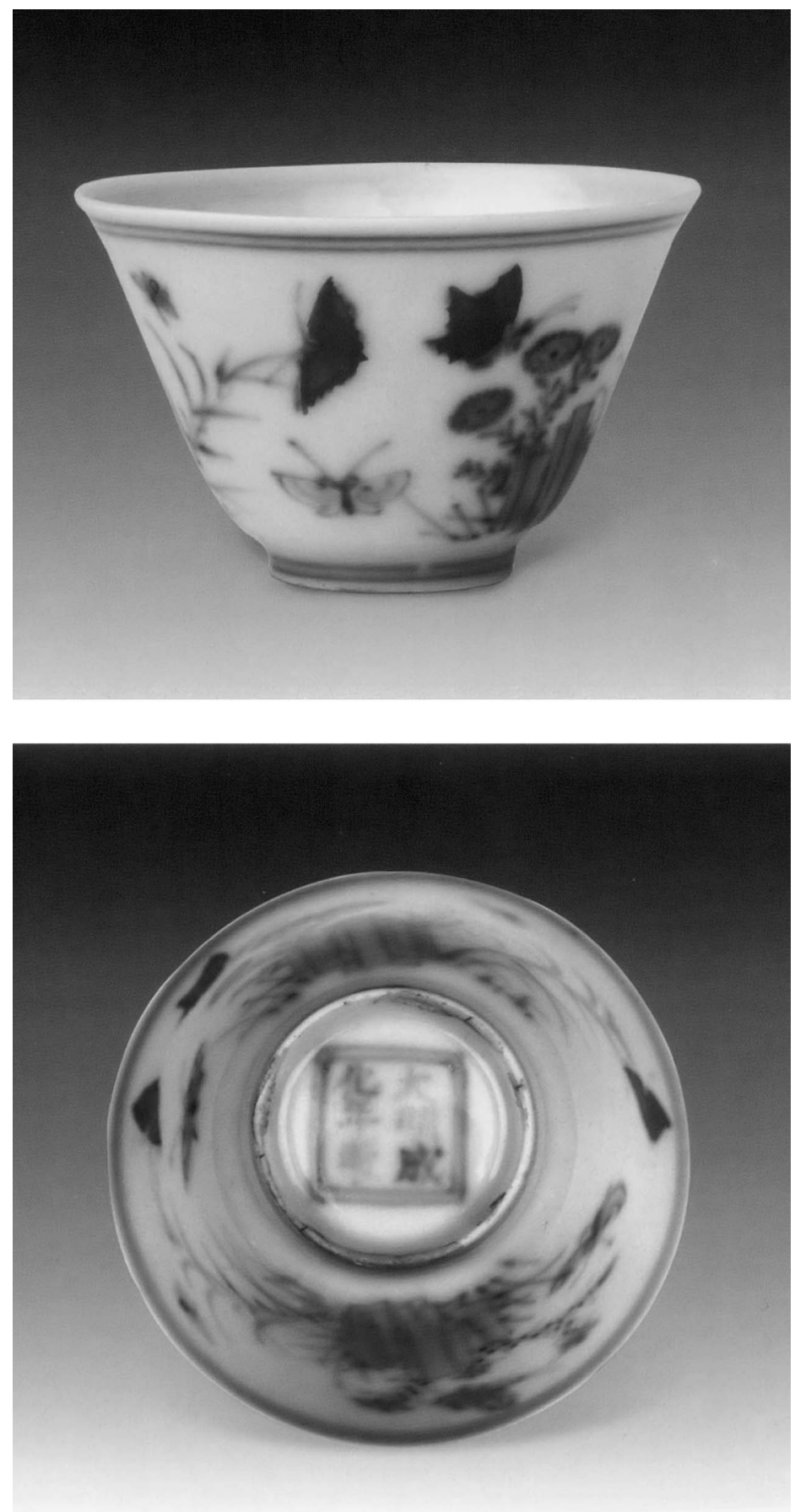

Fig. 3 Blue and white porcelain bowl, Ming dynasty, Chenghua reign (1465-87); $4.3 \mathrm{~cm}$ (height), $6.8 \mathrm{~cm}$ (mouth diameter), $2.6 \mathrm{~cm}$ (foot diameter). Inscription: "produced in the Chenghua reign of the Great Ming (Da Ming Chenghua nian zhi)" (Geng Baochang 2005: 95). 
Many annals in the history of technology and science attest to struggles over the causal dynamics between modes of (knowledge) appropriation and technological developments. Modern property regimes such as patents, trade secrets, copyright, guilds, and trademarks feature prominently within these debates, as factors or indicators of change and occasionally also as general yardsticks for a culture's assessment and approach toward scientific and technological invention and innovation. Such is also the case in Chinese history. Until the 1980s, a copious literature, predominantly in the field of economic analysis, pondered on the lack of such regulators or attempted to identify equivalents. These studies have left us with various incomplete impressions of the Chinese economics of ideas - that is, their ways of controlling material production and claiming rights within the whole circuit of production and usage, from the development and application of technologies to the actual allocation of the end product: a dominant central state system; a court and an elite who based their authorization on moral grounds and intellectual capability and arbitrarily took possession of things and affairs; a vast but mostly self-regulating space of trade and craftsmanship; a strong concern for real estate property rights; and a basic nonchalance toward intellectual property (Alford 1996: 1-9; Ganea, Pattloch, and Heath 2005: 5-8, 269). Research in recent decades has attempted to dismantle many of these propositions and assumptions, for example, by pointing to the multitude of local centers under central rule or the great role social and ritual underpinnings played within knowledge acquisition (Bol 2003; Qiu Pengsheng and Chen Xiyuan 2009). Much of this work concentrates on the Qing period, which, as the most recent, naturally offers a broader range of historical materials. For earlier periods, however, much work remains to be done, in particular on the conceptual basis. The means and methods by which knowledge was historically channeled were diverse. Inscriptions seem to have played a significant yet changing role in Ming material production for the expression, manifestation, and reception of rights and for the use of artifacts and the materials and technology with which they are produced. The Ming state and its elite, the scholars, established the trustworthiness of inscriptions by situating them within a traditional perspective as means of quality control and tax payment and by specifying their technical implementation. But the emperors, representing the state, employed the inscriptions quite selectively for the advertisements of their power and rights in fields such as porcelain and silk only. Within this context the emperors thus confirmed the reign marks as emblems of imperial rights. In the juxtaposition of practices and textual reflections, reign marks unfold as an emerging concept, not a deliberately designed one. While artifacts verify that the state effectively restricted the application of reign marks to wares produced by imperial manufacture and for imperial usage, written codification or contemporary textual reflection on such measurements is lacking. The same can be said about its actual purpose. Prima facie, a reign mark put the prevailing issues of this dynasty in its phase of establishment on display. The contextualization of the ware in time should have guaranteed quality and allowed the retracing of tax payments. However, since by the time of the Ming reign periods lasted for the entire duration of an emperor's rule, this claim was arbitrary. Introducing reign marks as an emblem of the state's power and rights to porcelain production, the Ming rulers dressed the field for diversified usages of inscriptions within commercialized structures. Discursive conventions filtered diversified usages to fit conventional schemes, but in fact both ideals and realities shifted enormously during the long rule of the Ming. What started with the bricks was 
different from what was accomplished in the bowl, not only in form and content but also in its status and role: a method to generate trust had developed into an instrument of trust, an emblem with a value in its own right.

\section{References}

Abercrombie, Thomas A. (1998). Pathways of memory and power: Ethnography and history among an Andean people. Madison: University of Wisconsin Press.

Alford, William P. (1996). To steal a book is an elegant offense: Intellectual property law in Chinese civilization. Stanford, CA: Stanford University Press.

Barbieri-Low, Anthony J. (2007). Artisans in early imperial China. Seattle: University of Washington Press.

Beijing tie yuan taoci yanjiuyuan 北京鐵源陶瓷研究院, Zhongguo di yi lishi dang'an guan 中國第一歷史 挡案館, ed. (2008). Qing gong taoqi dang'an quanji 清宫瓷器档案全集 (Complete collection of archival documents of porcelain utensils of the Qing). Beijing: Zhongguo huabao chubanshe.

Bernhardt, Kathryn (1999). Women and property in China: 960-1949. Stanford, CA: Stanford University Press.

Biermann, Irene A. (1998). Writing signs: The Fatimid public text. Berkeley and Los Angeles: University of California Press.

Blair, John, and Nigel Ramsay (1991). English medieval industries: Craftsmen, techniques, products. London: Hambledon.

Bol, Peter K. (2003). The "localist turn" and "local identity" in later imperial China. Late Imperial China 24: $1-50$.

Bray, Francesca (1997). Technology and gender: Fabrics of power in late imperial China. Berkeley and Los Angeles: University of California Press.

Brook, Timothy (1999). The confusions of pleasure: Commerce and culture in Ming China. Berkeley and Los Angeles: University of California Press.

Carré, Guillaume, and Christian Lamouroux (2010). Faux produits et marchandises contrefaites dans la Chine et le Japon prémodernes: Réglementations, corps de métiers et contraintes éthiques. ExtrêmeOrient, Extrême-Occident 32: 115-61.

Changling fajue weiyuan hui gongzuo dui 長陵發覺委員會工作隊 (1958). Ding Ling shijue jianbao 定陵 試掘簡報 (Concise report on the excavations of the Dingling tomb). Kaogu tongxun 7: 1-16. The second part was published in Kaogu tongxu (1959) 7: 358-74 under the same title.

Clunas, Craig (1997). Pictures and visuality in early modern China. London: Reaktion.

Clunas, Craig (2004) [1991]. Superfluous things: Material culture and social status in early modern China. Honolulu: University of Hawai'i Press.

Cowan, Ruth S. (1987). The consumption junction: A proposal for research strategies in the sociology of technology. In The social construction of technological systems: New directions in the sociology and history of technology, edited by Wiebe Bijker, Trevor Pinch, and Thomas Hughes, 261-80. Cambridge, MA: MIT Press.

Cui Shi 崔定 (1976). Zhenglun zhushi 政論注釋 (Exegesis of the discourses on administration). Shanghai: Renmin chubanshe.

Fan Jinmin 范金民 (1996). Mingchao shiqi de Nanjing jingji (1368-1644) 明朝時期的南京經濟 (13681644) (The economic life of Nanjing during the Ming dynasty, 1368-1644). In Nanjing jingji shi 南京 經濟史 (The economic history of Nanjing), edited by Chen Shengli 陳胜利, Mao Jiaqi 茅家琦, et al. Beijing: Zhongguo nongye keji chubanshe.

Farmer, Edward L. (1995). Zhu Yuanzhang and early Ming legislation: The reordering of Chinese society following the era of Mongol rule. Leiden: Brill.

Feng Xianming 馮先銘, ed. (2007). Zhongguo taoci jianchang 中國陶瓷鑒賞 (Appraisal of Chinese ceramics). Shanghai: Shanghai cishu chubanshe.

Ganea, Peter, Thomas Pattloch, and Christopher Heath (2005). Intellectual property law in China. The Hague: Kluwer Law International.

Gao Shiqi 高士奇 (1971) [1964]. Jin'ao tuishi biji 金鳌退食筆記 (Private jottings of Gao Shiqi after retirement). Taibei: Guanwen shuju.

Geng Baochang 耿宝昌 (2005). Sun Yingzhou de taoci shijie 孙瀛洲的陶瓷世界 (Sun Yingzhou's world of ceramics). Beijing: Zijincheng chubanshe. 
Golombek, Lisa, Robert B. Mason, and Patty Proctor (2001). Safavid potters' marks and the question of provenance. Iran 39: 207-36.

Guo Jinhai 郭金海 (2001). Mingdai Nanjing chengqiang zhuan mingwen luelun 明代南京城墻磚銘文略 論 (A discussion of the inscriptions on the Nanjing city wall). Dongnan wenhua 141: 75-78.

Gu Qiyuan 顧起元 (2002) [1618]. Kezuo zhuiyu 客座贅語 (Idle talk with guests). Shanghai: Shanghai guji chubanshe.

Gu Yingtai 谷應泰 (1986) [ca. 1621-1627]. Bowu yaolan 博物要覽 (Selected readings on the investigation of things). Taibei: Guang wen shuju.

Harris, William V. (1986). Ancient literacy. Cambridge, MA: Harvard University Press.

He Guoweng 何國衛 and Tang Zhifa 唐志拔 (1998). Dui Mingdai Liangshan guchuan de zihui ji yanjiu 對明代梁山古船的測繪及研究 (Measurement and research junk unearthed in Liangshan). Wuhan jiaotong keji daxue xuebao 22: 258-61.

Hobson, Robert L. (1923). The wares of the Ming dynasty. London: Benn Brothers.

Jin Risheng 金日升 (2002) [1628-44]. Song tian lu bi 頌天臚筆 (Private jottings of Song Tianlu). Shanghai: Shanghai guji chubanshe.

Kern, Martin (2001). Ritual, text, and the formation of the canon: Historical transitions of "wen" in early China. T'oung Pao 87: 43-91.

Kraus, Richard C. (1991). Brushes with power: Modern politics and the Chinese art of calligraphy. Berkeley and Los Angeles: University of California Press.

Liang Menglong 梁夢龍 and Wu Zhong 吳仲 (1981) [1578; 1940]. Haiyun xinkao 海運新考. (New study on sea waterways). Alternate title: Tong hui he zhi 通惠河志 (Report on the Tong hui river). Taibei: Guoli zhongyang tushuguan.

Li Dongyang 李東陽, Shen Shixing 申時行, et al. (2007) [1511; 1587]. Da Ming Huidian 大明會典 (Collected statutes of the Great Ming). Yangzhou: Guang ling shushe.

Li Tao 李壽 (1986) [1881]. Xu Zizhi tongjian changbian 續資治通鑒長編 (Comprehensive mirror to aid in government). Shanghai: Shanghai guji chubanshe.

Liu Sijie 劉斯潔 (jinshi 1547) (1999) [1580]. Tai cang kao 太倉考 (Investigations of the imperial granary). Beijing: Beijing tushuguan chubanshe.

Lu Hejiu 陸和九 (1981). Zhongguo jinshixue 中國金石學 (Epigraphic studies of China). Taibei: Mingwen shuju.

Ma Xigui 馬希桂 and Zhao Guanglin 趙光林, ed. (2005). Qinghuaming ci 青花名瓷 (Chinese blue and white porcelain). Jinan: Shandong meishu chubanshe.

Mills, Barbara J., and William H. Walker, eds. (2008). Memory work: Archaeologies of material practices. Santa Fe, NM: School for Advanced Research Press.

Patent Office Society, ed. (1936). Outline of the History of the United States Patent Office. Journal of Patent Trademark 18: 1-17.

Pierson, Stacey (1998). Women owners' marks on Chinese porcelain: Two case studies. Orientations 29: $51-54$.

Qiu Jun 邱濬 (1988) [1506]. Daxue yanyi bu 大學衍義補 (Supplement to the explanations of the great knowledge). Taibei: Shijie shuju.

Qiu Pengsheng 邱澎生 and Chen Xiyuan 陳熙遠 (2009). Ming Qing falü yun zuozhong de quanli yu wenhua 明清法律運作中的權力與文化 (Authority and culture in Ming and Qing law). Taibei: Zhong yang yan jiu yuan: Lian jing chu ban gong si.

Reed, Bradly W. (2000). Talons and teeth: County clerks and runners in the Qing dynasty. Stanford, CA: Stanford University Press.

Rowlands, Michael J. (1993). The role of memory in the transmission of culture. World Archaeology 25: $141-51$.

Schäfer, Dagmar (1998). Des Kaisers seidene Kleider: Staatliche Seidenmanufakturen in der Ming Zeit (1368-1644). Heidelberg: Edition Forum.

Siebert, Martina (2006). Pulu 譜錄: “Abhandlungen und Auflistungen” zu materieller Kultur und Naturkunde im traditionellen China. Frankfurt: Harrassowitz.

Siku quanshu zongmu 四庫全書總目 (Index of the complete library of the four treasuries), (2003) [174282]. Compiled by Yong Rong 永瑢. Beijing: Zhonghua shuju.

Sun Xun 孫洵 (2009). Mingdai Nanjing chengqiang kuangwen shufa shangping 明代南京城牆礦文書法賞 評 (Critical appraisal of the calligraphy of the brick inscriptions of the Ming dynastic Nanjing city wall). Shufa shangping 1: 41-47.

Sun Yan 孫彦, Zhang Jian 張健, and Wan Jinli 万金麗 (1999). Zhongguo lidai taoci tiji 中國歷代陶瓷題記 (Inscriptions on porcelain of historical China). Beijing: Beijing tushuguan chubanshe. 
Wang Guangyao 王光堯 (2010). Qianlong shiqi Yu yaochang de guanli tizhi he guanyang zhidu 乾乾隆時 期御窯廠的管理體制和官樣制度 (The system of official models and the relation between the imperial and private kilns during the Qianlong period). In Gongting yu difang: Shiqi zhi shiba shiqi de jishu jiaoliu 宮廷與地方:十七至十八時期的技術交流 (The palace and the locality: Technical exchange from the seventeenth to the eighteenth century), edited by Dagmar Schäfer (薛風), 31-75. Beijing: Zijincheng chubanshe.

Wang Guowei 王國維 (1927). Songdai zhi jinshi xue 宋代之金石學 (The study of bronzes and steles in the Song era). Guoxue luncong 1: 45-49.

Wang Kechang 王克昌, Wei Liping 韋立平, and Yang Xianwen 楊獻文 (1999). Ming Nanjing cheng qiang zhuan wen tu shi 明南京城墙磚文圖釋 (Annotated images of the brick inscriptions of the Ming dynasty Nanjing city wall). Nanjing: Nanjing chubanshe.

Wang Xiuling 王秀玲 (2001). Ding Ling chutu de sizhi pin 定陵出土的絲織品 (Silk artifacts excavated from the Ding Ling tomb). Jianghan kaogu 1: 80-88.

Wilson, Ming (1998). Rare marks on Chinese ceramics. London: School of Oriental and African Studies.

Xia Minghua 夏明華 (2003). Jingzhou gucheng leming yu wule gongming 荆州古城勒名與物勒工名 (Discussion on inscribed bricks from ancient Jingzhou city). Jianghan kaogu 87: 66-72.

Xie Zhaozhe 谢肇淛 (1935) [1640]. Wuza zu: Wan Ming biji 五雜组:晚明筆記 (Five vessels: A private jotting of the late Ming). Edited by Jinxia ge zhu ren, Zhang Yiping 襟霞閣主人，章衣萍 (1902-?). Shanghai: Zhongyang shudian.

Xu Song 徐松 (1957) [1809; 1936]. Song huiyao jigao 宋會要輯稿 (Chronological index to collected statutes of the Song dynasty reconstructed). Beijing: Zhonghua shuju.

Xu Zhiheng 許之衡 (1992). Yinliu zhai shuci 飲流齋說瓷 (Discourse on porcelain from the Yinliu studio). Yangzhou: Huangshan shushe.

Yang Guoqing 楊國慶 (2002). Ming Nanjing chengqiang zhu cheng renyuan goucheng ji yong gongliang chutan 明南京城牆築城人員構成及用工量初探 (A preliminary study on the staff and amount of engineering in the project of city wall of Nanjing in Ming dynasty). Dongnan wenhua 153(1): 37-44.

Yang Guoqing 楊國慶 (2008). Nanjing chengqiang zhuanwen 南京城牆磚文 (Brick inscriptions of the Nanjing city wall). Nanjing: Shifan daxue chubanshe.

Yang Guoqing 楊國慶 and Wang Zhigao 王志高 (2008). Nanjing chengqiangzhi 南京城牆志 (An account of the Nanjing city wall). Nanjing: Fenhuang chubanshe.

Zhang Rong 張榮 (1997). Mingdai qiqi de kuanzhi ji weikuan bianxi 明代漆器的款識及偽款辨析 (An analysis of inscriptions on Ming dynastic lacquerwares and their forgery). Shoucang jia 6: 28-33.

Zhang Tingyu 張廷玉 et al. (1991) [1736]. Ming shi 明史 (Ming annals). Beijing: Zhonghua shuju.

Zhao Feng 趙豐 (2005). Zhongguo Sichou yishu shi 中國絲綢藝術史 (A history of the art of Chinese silk). Beijing: Wenwu chubanshe.

Zhou Yunzhong 周運中 (2005). Nanjing Ming chengkuang mingwen xintan 南京明成礦銘文新探 (A new explanation of Nanjing city wall brick inscription). Dongnan Wenhua 186(4): 70-72.

Zhu Jingcheng 朱金升 (1978). Hebei cixian nankai hecun Yuan dai muchuan fajue jianbao 河北磁縣南開 河村元代木船發掘簡報. (Brief report on the wooden grain river boats of the Yuan dynasty excavated in Heibei Province, Xi Xian County, Nankai River Village). Kaogu 6: 388-401. 